\title{
EFFECT OF TYTANIT® ON THE PHYSIOLOGICAL ACTIVITY OF WILD STRAWBERRY (FRAGARIA VESCA L.) GROWN IN SALINITY CONDITIONS
}

\author{
- Research paper - \\ Alicja AURIGA ${ }^{1 *}$, Jacek WRÓBEL*, Ireneusz OCHMIAN** \\ *Department of Bioengineering, West Pomeranian University of Technology in Szczecin, \\ Stowackiego 17, 71-434 Szczecin \\ ** Department of Horticulture, West Pomeranian University of Technology in Szczecin, Stowackiego \\ 17, 71-434 Szczecin
}

\begin{abstract}
Progressive global warming and decreasing freshwater resources are forcing to look for alternative solutions in plants cultivation. The use of saltwater and cultivation in saline areas becomes increasingly common. Wild strawberry is a rich source of antioxidant compounds beneficial for human health. The aim of the study was to investigate the effect of Tytanit ${ }^{\circledR}$ on the physiological activity of wild strawberry grown under different salinity levels (32.5, 50 and $100 \mathrm{mM} \mathrm{L}^{-1} \mathrm{NaCl}$ ). Assimilatory pigments content, free proline concentration, chlorophyll fluorescence and relative water content were measured at two phenological phases BBCH 15 and 60. Results analysis revealed that the applicability of Tytanit@ to mitigate physiological stress in wild strawberry caused by salinity did not produce the desired effect.
\end{abstract}

Key words: chlorophyll-a, chlorophyll-b, carotenoids, proline, chlorophyll fluorescence, water balance.

\section{INTRODUCTION}

In research on the influence of unfavorable environmental factors on physiological activity of plants, solutions are sought to optimize plants growth and development conditions. The most frequently applied solution is utilization of natural or mineral fertilizers, growth regulators or protective preparations. Tytanit ${ }^{\circ}$ is a trade name for a liquid, mineral plant growth and yield stimulator the main component of which is titanium (Ti). The beneficial effect of Ti has been confirmed by a number of scientific reports revealing its influence on the increase in the activity of iron ions, vigour of pollen grains, rate of nutrient uptake, and the improvement of plant health status (Michalski, 2008; Borkowski et al., 2017). Freshwater scarcity, environmental pollution and salinisation of soil and water are significant problems at global level. According to Jamil et al. (2011) and Shrivastava and Kumar (2015) high salinity afflicts about $20 \%$ of total crops and $33 \%$ of irrigated agricultural lands worldwide. Further predictions indicate that with the increase of salinized areas at $10 \%$ rate annually

Received: 06.10.2020.

Accepted in revised form: 07.12.2020 over $50 \%$ of the arable land would be salinized by the year 2050 .

Salinity causes a decrease in cultivated area, yield and quality of crops (Yamaguchi et al., 2005; Shahbaz et al., 2013). More than half of the crop species is sensitive to even relatively low salinity. Excess salt in the root zone lowers the amount of water available to plants (Zhu, 2001). Plants exposed to prolonged salinity suffer from ionic stress which usually appears as premature ageing of leaves. This results in a reduction in the total photosynthetic area and thus plant productivity (Sultana et al., 1999; Muscolo et al., 2003).

Wild strawberry (Fragaria vesca L.) belongs to the family Rosaceae. $F$. vesca is mostly known for its aromatic fruits, however, almost whole plant has medicinal or therapeutic properties. Leaves and stems contain important antioxidant agents such as silicium acids, quercetin and flavonoids. Fruits are rich in vitamins $\mathrm{C}, \mathrm{A}, \mathrm{B}$, and mineral salts: iron, calcium, phosphorus and cobalt (Yurdugul, 2008). High antioxidant content makes the species beneficial for human health. Enriching daily diet in wild strawberry prevents premature ageing, supports the immune system, helps control: diabetes, high blood pressure, high cholesterol, and lowers the risk of cancer. Nevertheless, due to their

${ }^{1}$ Corresponding author. E-Mail address: alicja.auriga@o2.pl 
specific taste and intense aroma and high antioxidant content, wild strawberries are valued and sought by the fresh fruit markets, the processing industry, confectionery and cosmetics industries. That contributes to a high market value of Fragaria vesca, which may encourage farmers to increase the cultivation area of this species (Muñoz et al., 2011; Oancea, 2011; Dias et al., 2016; Kruczek et al. 2020).

The literature so far has focused mainly on the evaluation of the influence of Tytanit ${ }^{\circledR}$ on the yield and its quality in various plant species. There are few reports investigating the issue of its protective properties based on physiological mechanisms observed in plants. Most of this type of research is carried out on popular cultivated plants (3c). There are few reports concerning niche species, such as wild strawberry (Fragaria vesca L.), which becomes increasingly popular in Poland due to its taste and biological properties.

The aim of the experiment was to investigate an influence and effectiveness of Tytanit ${ }^{\circledR}$ on the physiological activity of wild strawberry of Baron von Solemacher variety cultivated in saline conditions.

\section{MATERIAL AND METHODS}

\section{Plant material and experimental design}

The vase experiment was carried out in 2016-2017 in the period from April to September in the vegetation hall of the West Pomeranian University of Technology in Szczecin. The experimental material was the wild strawberry Fragaria vesca L. var. Baron von Solemacher, grown in a medium with three levels of salinity in the presence or absence of Tytanit ${ }^{\circledR}$.

The wild strawberry variety tested is characterized by medium tolerance to salinity and high yield. The variety grows up to $20 \mathrm{~cm}$ high, has elongated red or cream-colored fruit, rich in vitamins B and mineral salts: iron, calcium, phosphorus, cobalt.

Each year, wild strawberry seeds were sown into a ready-made garden substrate on the basis of peat and sand. The substrate had $\mathrm{pH} 6$, salinity 32.5 $\mathrm{mM} \mathrm{L}^{-1} \mathrm{NaCl}$ and starting dose of multi-compound fertilizer with the composition of NPK $14+16+18$ in the amount of $0.6 \mathrm{~kg} \mathrm{~m}^{-3}$. After 6 weeks, young seedlings were moved into vases with the volume of $1 \mathrm{dm}^{3}$ and placed in a vegetation hall. Planted seedlings of wild strawberry were daily irrigated with distillate water up to minimal seepage of the substrate. The substrate moisture was maintained within the range of $2.2-1.7 \mathrm{pF}$.

The vase experiment was established in the system of random blocks in three repetitions of 8 plants each. The first factor was the 3-degrees of substrate salinity: $\mathrm{S} 1$ - ready-made substrate salinity $32.5 \mathrm{mM} \mathrm{L}^{-1} \mathrm{NaCl}$; $\mathrm{S} 2-50 \mathrm{mM} \mathrm{L}^{-1} \mathrm{NaCl}$; $\mathrm{S} 3-100 \mathrm{mM} \mathrm{L}^{-1} \mathrm{NaCl}$, The second factor was the use of Tytanit ${ }^{\circledR}(\mathrm{T})$ - $8.5 \mathrm{~g}$ of titanium per liter of preparation - in one dose at all salinity levels: $\mathrm{S} 1+\mathrm{T}, \mathrm{S} 2+\mathrm{T}, \mathrm{S} 3+\mathrm{T}$. The substrate was watered with a solution of $0.3 \%$ concentration $(30 \mathrm{ml}$ of stimulator in $100 \mathrm{~L}$ water) in three stages of plant development after seedlings rooting: 2-3 leaf developed, 5-8 leaf developed and at the beginning of flowering, according to the manufacturer's recommendations. The control was performed on plants cultivated on a substrate with salinity of S1 without treatment with Tytanit ${ }$. The measurements of selected parameters were performed in two phenological phases of BBCH 15 (5th leaf developed) and $\mathrm{BBCH} 60$ (first flowers open). The material for chemical analyses consisted of leaves taken from the plant rosette center. Moreover, after the experiment, the substrate analysis was performed to determine the changes in macroelements content and salinity.

\section{Assimilatory Pigments}

A fresh leaves of $F$. vesca were used to determine the content of assimilatory pigments: chlorophyll-a and chlorophyll-b by the Arnon's method (1956) as modified by Lichtenthaler and Wellburn (1983). The content of carotenoids was assayed according to the Hager and Mayer-Berthenrath's (1966) method. The leaves were homogenised with $10 \mathrm{ml}$ of $80 \%$ acetone and the optical density of the obtained supernatants was determine on a spectrophotometer at 440, 645, and $663 \mathrm{~nm}$ wavelengths.

\section{Chlorophyll fluorescence}

Fluorescence of chloropchyll-a was measured with the Hanstech Intrument Handy PEA fluorimeter on completely darkened leaves and after light exposure. Two parameters were selected to evaluate the reaction of plants to salinity and Tytanit $\AA$ : $\mathrm{Fv} / \mathrm{Fm}$ - maximum potential photochemical activity and Fv/Fo - maximum water fission efficiency on the donor side of PSII.

\section{Proline (Pro) determination}

The concentration of free proline in fresh wild strawberry leaves was determined using the ninhydrin reaction according to the method developed by Bates et al. (1973). $0.5 \mathrm{~g}$ of fresh 
plant tissue was homogenized in the presence of $3 \%$ salicylic acid aqueous solution $(10 \mathrm{ml})$ and the homogenate was filtered through a tissue paper filter. $2 \mathrm{ml}$ of acid ninhydrin and $2 \mathrm{ml}$ of glacial acetic acid were added to the upper aqueous phase. Then the whole was mixed and placed in a closed tube in a greenhouse set at $90-100^{\circ} \mathrm{C}$. After 1 hour, the tubes were transferred to an ice bath for 15 minutes to cool. Then $4 \mathrm{ml}$ of toluene was added to each tube and shaken for $30 \mathrm{~min}$. The samples prepared in this way were left for phase separation. The upper phase (toluene) was collected to determine the absorbance of chromophore in the presence of a blank at a wavelength of $\lambda=520 \mathrm{~nm}$ (Auriga et al. 2018).

\section{Water balance}

The water balance in wild strawberry leaves was determined by calculating the following indicators:
RWC - relative water content, and WSD - water saturation deficit (Yamasaki and Dillenbu 1999) according to the following equations: RWC = [(fresh weight- dry weight) / (turgid weight - dry weight $)] \times 100 ;$ WSD $=[($ turgid weight - dry weight) - (fresh weight - dry weight) / (turgid weight - dry weight)] x 100. The procedure was performed according to the method described by Wróbel et al. (2016).

\section{Statistics}

The results of the study were subjected to multifactor analysis of variance ANOVA. Homogeneous groups were determined using Tukey's test at the significance level of $\alpha=0.05$. The results being presented in all tables are the averaged results from gathered data.

\section{RESULTS AND DISCUSSION}

The results on the susbstrate analysis are presented in Table 1. The results showed the effect of Tytanit ${ }^{\circledR}$ on the increase in the content of elements $\mathrm{K}, \mathrm{Ca}, \mathrm{Mg}, \mathrm{Na}$ in the medium with the lowest salinity compared to the variant without using the preparation. In substrates with higher salinity in which Tytanit ${ }^{\circledR}$ was used, lower values were noted for all nutrients except nitrogen in the $\mathrm{S} 3+\mathrm{T}$ variant. The content of this element was the highest among the tested variants $\left(95 \mathrm{mg}^{-1}\right)$.

\section{Chlorophylls and carotenoids}

The highest coefficient of an influence on chlorophyll-a and carotenoids content was noted for salinity, $\mathrm{P}=32.07 \%$ and $\mathrm{P}=30.70 \%$, respectively. The interactions between salinity and date $\mathrm{P}=24.17 \%$ and $\mathrm{P}=29.27 \%$ and between Tytanit ${ }^{\circledR}$ use and salinity $\mathrm{P}=15.10 \%$ and $\mathrm{P}=16.08 \%$ were also significant (Tab. 2). The most significant influence on chlorophyll-b content was found for salinity $\mathrm{P}=27.34 \%$, lower interaction between the use of Tytanit ${ }^{\circledR}$ and the term $\mathrm{P}=20.94 \%$ and the use of Tytanit ${ }^{\circledR}$ alone $\mathrm{P}=12.27 \%$. Among the studied factors, the lowest influence on the content of assimilatory pigments was observed for the time of measurement.

In the first period of measurement, regardless of the substrate salinity level, no significant effect of Tytanit ${ }^{\circledR}$ on the content of individual assimilatory pigments was observed. Although the differences were insignificant, more of them were found in $\mathrm{S} 1+\mathrm{T}$ objects (Tab. 3). In BBCH 60 was observed a 2-3-fold decrease in pigments content after an application of the preparation in the highest salinity conditions. In general, the higher the salinity, the larger the decrease in pigments content. However, Tytanit ${ }^{\circledR}$ significantly increased the concentration of chlorophyll-a and $b$ and carotenoids in plants grown on substrate S1. Their content in the first and second period of measurement was as follows: chl a 1.921 and 2.185 $\mathrm{mg} \mathrm{kg} \mathrm{kg}^{-1}$; chl b 0.700 and $0.783 \mathrm{mg} \mathrm{kg}$; carotenoids 4.008 and $5.014 \mathrm{mg} \mathrm{kg}^{-1}$, respectively.

Table 1. Analysis of the substrate.

\begin{tabular}{|c|c|c|c|c|c|c|c|c|c|}
\hline \multirow{2}{*}{ Variant } & \multirow{2}{*}{$\begin{array}{l}\mathrm{pH} \text { in } \\
\mathrm{H} 2 \mathrm{O}\end{array}$} & \multicolumn{7}{|c|}{$\mathrm{mg} \mathrm{l}^{-1}$} & \multirow{2}{*}{$\begin{array}{l}\text { Salinity in } \\
\mathrm{g} \mathrm{NaCl}^{-1}\end{array}$} \\
\hline & & $\mathrm{N}-\mathrm{NO} 3$ & $\mathrm{P}$ & $\mathrm{K}$ & $\mathrm{Ca}$ & $\mathrm{Mg}$ & $\mathrm{Na}$ & $\mathrm{Cl}$ & \\
\hline $\mathrm{S} 1$ & 6.0 & 72 & 43 & 327 & 1923 & 200 & 259 & 170 & 1.91 \\
\hline $\mathrm{S} 2$ & 6.1 & 50 & 47 & 352 & 2047 & 224 & 1802 & 2260 & 5.51 \\
\hline S3 & 6.0 & 72 & 44 & 378 & 1898 & 200 & 2387 & 4450 & 10.86 \\
\hline $\mathrm{S} 1+\mathrm{T}$ & 6.2 & 64 & 41 & 366 & 2118 & 244 & 308 & 189 & 1.90 \\
\hline $\mathrm{S} 2+\mathrm{T}$ & 6.0 & 68 & 44 & 325 & 2038 & 222 & 1600 & 1940 & 5.97 \\
\hline $\mathrm{S} 3+\mathrm{T}$ & 6.0 & 95 & 43 & 383 & 1918 & 211 & 2347 & 4070 & 10.23 \\
\hline
\end{tabular}

$\mathrm{S} 1$ - substrate with slinity $32.5 \mathrm{mM} \mathrm{L}^{-1} ; \mathrm{S} 2-50 \mathrm{mM} \mathrm{L}^{-1} ; \mathrm{S} 3-100 \mathrm{mM} \mathrm{L}^{-1} ; \mathrm{T}-0.3 \%$ solution of Tytanit ${ }^{\circledR}$ 
Table 2. ANOVA table for pigments content, proline content, Fv/Fm and Fv/Fo.

\begin{tabular}{|l|r|r|r|r|r|r|r|r|r|r|r|r|}
\multicolumn{1}{c|}{} & \multicolumn{2}{c|}{ Chl-a } & \multicolumn{2}{c|}{ Chl-b } & \multicolumn{2}{c|}{ Carotenoids } & \multicolumn{2}{c|}{ Pro } & \multicolumn{2}{c|}{ Fv/Fm } & \multicolumn{2}{c|}{ Fv/Fo } \\
\hline $\begin{array}{l}\text { Source of } \\
\text { variance }\end{array}$ & $\mathrm{p}$ & $\mathrm{P}(\%)$ & $\mathrm{p}$ & $\mathrm{P}(\%)$ & $\mathrm{p}$ & $\mathrm{P}(\%)$ & $\mathrm{p}$ & $\mathrm{P}(\%)$ & $\mathrm{p}$ & $\mathrm{P}(\%)$ & $\mathrm{p}$ & $\mathrm{P}(\%)$ \\
\hline $\mathrm{a}$ & 0,000 & $\mathbf{5 . 5 6}$ & 0.000 & $\mathbf{1 2 . 2 7}$ & 0.000 & $\mathbf{4 . 3 4}$ & 0.000 & $\mathbf{0 . 5 3}$ & 0.910 & $\mathbf{0 . 0 0}$ & 0.765 & $\mathbf{0 . 0 3}$ \\
\hline $\mathrm{b}$ & 0,000 & $\mathbf{3 2 . 0 7}$ & 0.000 & $\mathbf{2 7 . 4 0}$ & 0.000 & $\mathbf{3 0 . 7 0}$ & 0.000 & $\mathbf{5 6 . 8 4}$ & 0.000 & $\mathbf{2 5 . 0 9}$ & 0.000 & $\mathbf{2 6 . 5 4}$ \\
\hline $\mathrm{c}$ & 0,000 & $\mathbf{4 . 2 6}$ & 0.618 & $\mathbf{0 . 1 3}$ & 0.040 & $\mathbf{1 . 2 4}$ & 0.000 & $\mathbf{2 8 . 9 3}$ & 0.000 & $\mathbf{3 7 . 2 8}$ & 0.000 & $\mathbf{2 5 . 8 8}$ \\
\hline $\mathrm{a} \times \mathrm{b}$ & 0,000 & $\mathbf{1 5 . 1 0}$ & 0.007 & $\mathbf{6 . 2 6}$ & 0.000 & $\mathbf{1 6 . 0 8}$ & 0.000 & $\mathbf{1 . 7 8}$ & 0.084 & $\mathbf{0 . 1 9}$ & 0.247 & $\mathbf{0 . 4 8}$ \\
\hline $\mathrm{a} \times \mathrm{c}$ & 0,000 & $\mathbf{8 . 3 4}$ & 0.000 & $\mathbf{2 0 . 9 4}$ & 0.000 & $\mathbf{7 . 3 2}$ & 0.022 & $\mathbf{0 . 1 6}$ & 0.224 & $\mathbf{0 . 1 9}$ & 0.375 & $\mathbf{0 . 7 0}$ \\
\hline $\mathrm{b} \times \mathrm{c}$ & 0,000 & $\mathbf{2 4 . 1 7}$ & 0.001 & $\mathbf{1 0 . 0 2}$ & 0.000 & $\mathbf{2 9 . 2 7}$ & 0.000 & $\mathbf{1 1 . 0 8}$ & 0.000 & $\mathbf{3 2 . 0 4}$ & 0.000 & $\mathbf{1 7 . 1 1}$ \\
\hline a $\times \mathrm{b} \times \mathrm{c}$ & 0,002 & $\mathbf{4 . 3 9}$ & 0.000 & $\mathbf{1 0 . 9 2}$ & 0.001 & $\mathbf{4 . 7 3}$ & 0.410 & $\mathbf{0 . 0 5}$ & 0.342 & $\mathbf{0 . 1 4}$ & 0.234 & $\mathbf{1 . 0 4}$ \\
\hline Error & & $\underline{6.11}$ & & $\underline{12.05}$ & & $\underline{6.30}$ & & $\underline{0.63}$ & & $\underline{5.07}$ & $\underline{28.21}$ \\
\hline Total & & 100.0 & & 100.0 & & 100.0 & & 100.0 & & 100.0 & & 100.0 \\
\hline
\end{tabular}

$\mathrm{a}$ - Tytanit ${ }^{\circ} ; \mathrm{b}$ - salinity; $\mathrm{c}$ - phenological phase; $\mathrm{p}$ - probability of error; $\mathrm{P}(\%)$ - percentage of contribution

Tab. 3. Effect of the performed treatments on pigments content ( $\mathrm{mg} \mathrm{g}^{-1} \mathrm{f}$.w.) and free proline content ( $\mu$ mol $\mathrm{g}^{-1} \mathrm{f} . \mathrm{w}$.) in the leaves of the tested wild strawberry. Means with same letter were not significantly different by Tukey's comparison at $\mathrm{p}<0.05$ level.

\begin{tabular}{|c|c|c|c|c|c|c|}
\hline \multirow[b]{2}{*}{ Salinity } & \multicolumn{2}{|c|}{ BBCH15 } & \multicolumn{4}{|c|}{ ВBCH60 } \\
\hline & 0 & $\mathrm{~T}$ & average & 0 & $\mathrm{~T}$ & average \\
\hline \multicolumn{7}{|c|}{ Chlorophyll-a (mg g ${ }^{-1}$ f.w.) } \\
\hline S1 & $1.651^{\mathrm{bcd}}$ & $1.921^{\mathrm{ab}}$ & $1.786^{\mathrm{B}}$ & $2.007^{\mathrm{ab}}$ & $2.185^{\mathrm{a}}$ & $2.096^{A}$ \\
\hline $\mathrm{S} 2$ & $1.777^{\mathrm{bc}}$ & $1.736^{\mathrm{bcd}}$ & $1.756^{B}$ & $1.852^{\mathrm{abc}}$ & $1.396^{\mathrm{d}}$ & $1.624^{\mathrm{B}}$ \\
\hline S3 & $1.758^{\mathrm{bcd}}$ & $1.663^{\mathrm{bcd}}$ & $1.710^{\mathrm{B}}$ & $1.535^{\mathrm{cd}}$ & $0.497^{\mathrm{e}}$ & $1.016 \mathrm{C}$ \\
\hline average & $1.729^{\mathrm{A}}$ & $\mathbf{1 . 7 7 3}^{\mathrm{A}}$ & & $1.797^{\mathrm{A}}$ & $1.359^{\mathrm{B}}$ & \\
\hline \multicolumn{7}{|c|}{ Chlorophyll-b (mg g ${ }^{-1}$ f.w.) } \\
\hline S1 & $0.605^{\mathrm{c}}$ & $0.700^{\mathrm{abc}}$ & $0.653^{\mathrm{B}}$ & $0.836^{\mathrm{a}}$ & $0.783^{\mathrm{ab}}$ & $0.810^{\mathrm{A}}$ \\
\hline S2 & $0.666^{\mathrm{bc}}$ & $0.695^{\mathrm{abc}}$ & $0.681^{B}$ & $0.780^{\mathrm{ab}}$ & $0.611^{\mathrm{c}}$ & $0.695^{\mathrm{B}}$ \\
\hline S3 & $0.699^{\mathrm{abc}}$ & $0.661^{\mathrm{bc}}$ & $0.680^{B}$ & $0.748^{\mathrm{abc}}$ & $0.326^{\mathrm{d}}$ & $\mathbf{0 . 5 3 7} 7^{\mathrm{C}}$ \\
\hline average & $0.657^{\mathrm{B}}$ & $0.685^{B}$ & & $\mathbf{0 . 7 8 8 ^ { \mathrm { A } }}$ & $\mathbf{0 . 5 7 3} \mathrm{C}$ & \\
\hline \multicolumn{7}{|c|}{ Carotenoids ( $\mathrm{mg} \mathrm{g}^{-1}$ f.w.) } \\
\hline $\mathrm{S} 1$ & $3.445^{\mathrm{cde}}$ & $4.008^{\mathrm{bcd}}$ & $3.727^{\mathrm{B}}$ & $4.387^{\mathrm{ab}}$ & $5.014^{\mathrm{a}}$ & $4.700^{A}$ \\
\hline S2 & $3.720^{\text {bcde }}$ & $3.777^{\text {bcde }}$ & $3.74^{\mathrm{B}}$ & $4.219^{\mathrm{abc}}$ & $3.078^{\mathrm{e}}$ & $3.650^{B}$ \\
\hline S3 & $3.836^{\text {bcde }}$ & $3.564^{\text {bcde }}$ & $3.700^{B}$ & $3.289^{\mathrm{de}}$ & $1.111^{\mathrm{f}}$ & $2.200^{\mathrm{C}}$ \\
\hline average & $3.667^{\mathrm{A}}$ & $3.783^{\mathrm{A}}$ & & $3.965^{\mathrm{A}}$ & $3.068^{B}$ & \\
\hline \multicolumn{7}{|c|}{ Proline ( $\mu \mathrm{mol} \mathrm{g}{ }^{-1}$ f.w. $)$} \\
\hline S1 & $0.585^{\mathrm{f}}$ & $0.283^{\mathrm{f}}$ & $0.434^{\mathrm{D}}$ & $1.048^{\mathrm{e}}$ & $1.108^{\mathrm{e}}$ & $1.078^{\mathrm{C}}$ \\
\hline S2 & $0.445^{\mathrm{f}}$ & $0.527^{f}$ & $0.486^{\mathrm{D}}$ & $1.415^{\mathrm{de}}$ & $1.752^{\mathrm{cd}}$ & $1.583^{B}$ \\
\hline S3 & $2.100^{\mathrm{c}}$ & $1.365^{\mathrm{de}}$ & $1.733^{\mathrm{B}}$ & $4.905^{\mathrm{a}}$ & $4.229^{b}$ & $4.567^{A}$ \\
\hline average & $1.044^{\mathrm{B}}$ & $0.725^{C}$ & & $2.456^{\mathrm{A}}$ & $2.363^{A}$ & \\
\hline
\end{tabular}

$\mathrm{S} 1$ - substrate with slinity $32.5 \mathrm{mM} \mathrm{L}^{-1} ; \mathrm{S} 2-50 \mathrm{mM} \mathrm{L}^{-1} ; \mathrm{S} 3-100 \mathrm{mM} \mathrm{L}{ }^{-1} ; 0$ - lack of Tytanit@; T - 0.3\% solution of Tytanit@

The study showed a significant decrease in the mean content of assimilatory pigments caused by salinity of the substrate in later phenological phases (II term). This confirms the literature reports on the plant reactions to this factor (Sahat et al., 2010; Chutipaijit et al., 2011; Parihar et al., 2015). Rahimi et al. (2011) in the experiment with strawberry (Fragaria ananassa cv. Camarosa) showed a decrease in chlorophyll-a content depending on the degree of substrate salinity, by about $15 \%$ for $60 \mathrm{mM} \mathrm{L}^{-1} \mathrm{NaCl}$ and $36 \%$ for 90 $\mathrm{mM} \mathrm{L}{ }^{-1} \mathrm{NaCl}$ compared to the control. In the case of chlorophyll-b it was about $26 \%$ and $41 \%$, respectively. In our study, a decrease of about $8 \%$ and $24 \%$ for chlorophyll-a and about $7 \%$ and $10.5 \%$ for chlorophyll-b was noted for salinity of 50 and $100 \mathrm{mM} \mathrm{L}^{-1} \mathrm{NaCl}$. This may suggest better salinity resistance of wild strawberry compared to strawberry. Changes in the content of photosynthetic pigments are also dependent on the tolerance of the plants to salinity of the substrate, i.e., their genotype (Garc1, 2002; Noreen et al., 2009). On the other hand, a positive effect of salinity on the content of assimilatory pigments was noted in studies on rice (Belkhodja et al., 1999) and tomato (Romero-Aranda et al., 2001). 
Similar results were obtained in our experiment, but only in the first phenological phases (first term of measurement). An increase in the content of assimilatory pigments under the influence of salinity in the first period of ontogenesis was associated with a decrease in hydration of leaf assimilating tissue, and thus with a higher concentration of pigments per mass unit (Wróbel et al., 2016).

In turn, the observed significant decrease in assimilatory pigments under the influence of salinity in later phenological phases (II term) might be associated with a decrease in metabolic activity of the organism. It could be result from strong dehydration of cells, and thus decreased synthesis of chlorophyll and carotenoids. Lowest pigments values recorded at $\mathrm{BBCH} 60$ for plants $\mathrm{S} 3+\mathrm{T}$ may indicate an unfavorable effect of Tytanit ${ }^{\circledR}$ on plants cultivated under extreme conditions. The very low pigments content compare to other variants suggests a decrease in photosynthesis and may designate preparation's enhancement of the toxic effect of salt on the plant.

Significant positive effect of Tytanit ${ }^{\circledR}$ on physiological-biochemical activity of wild strawberry was observed only in unsalted substrate, regardless of the phenological phase. Positive effect of titanium dioxide on chlorophyll$\mathrm{a},-\mathrm{b}$ and carotenoids content was confirmed in many publications(Carvajal et al. 1998; Hrubý et al. 2002; Samadi, 2014; Samadi et al., 2015). According to Kuzel et al. 2003, titanium causes apparent deficiency of $\mathrm{Fe}$ and $\mathrm{Mg}$, contributing to a greater absorption of $\mathrm{Fe}$ and other metals by roots. Iron, on the other hand, is crucial for chlorophyll formation and photosynthesis rate (Nadi et al., 2013). It also has an important effect on enzymatic systems and plant respiration (Mir et al., 2015). In turn, an increased carotenoid content may be the result of an increased synthesis of this pigment caused by suppression of reactive oxygen species by heavy metals (Samadi, 2014).

\section{Proline}

The research revealed a significant influence of all studied factors on proline content in wild strawberry leaves (Tab. 2). The salinity $\mathrm{P}=56.84 \%$, and the term $\mathrm{P}=28.93 \%$ had the most significant effect, while the lowest was noted for Tytanit ${ }^{\circledR}$ $\mathrm{P}=0.53 \%$.

Plants cultivated under conditions of the highest salinity were characterized by a considerably high amount of proline regardless of the date of measurement (Tab.3). In general, older plants (BBCH 60) had significantly higher proline content compared to younger plants (BBCH 15).
Tytanit ${ }^{\circledR}$ treatment significantly decreased proline accumulation only in plants in BBCH 15 - variants with $\mathrm{T}$ absence 1.044 and variants with $\mathrm{T}$ presence $0.725 \mu \mathrm{mol} \mathrm{g}{ }^{-1}$ f.w. - and had no significant effect on older plants.

Proline is an enzyme which main function in the plant is to stabilize proteins and protect cell membranes. It also acts as an osmoprotector and is a reservoir of nutrients, mainly carbon and nitrogen (Islam et al., 2009; Zouari et al. 2016). It is considered to be one of the main salt stress biomarkers (Gomes et al., 2017). Its content in the plant depends on many biotic and abiotic factors (Karolewski 1996).

Rahimi et al. (2011) recorded a fourfold increase in proline content in strawberry leaves in case of substrate salinity of $60 \mathrm{mM} \mathrm{L}^{-1}$ and a fivefold increase for salinity of $90 \mathrm{mM} \mathrm{L} \mathrm{L}^{-1}$. In our experiment the concentration of Pro slightly increased at salinity of $50 \mathrm{mM} \mathrm{L}^{-1}$, whereas at salinity of $100 \mathrm{mM} \mathrm{L}^{-1}$ the result was four times higher compared to the control. This may indicate a different level of both species reaction to salt stress. Plants treated with Tytanit ${ }^{\circledR}$ were characterized in both terms by a lower mean Pro content compared to untreated plants, which may indicate the anti-stress effect of this preparation. However, there are no reports on this subject in the literature.

\section{RWC and WSD}

Statistical analysis showed a significant influence of salinity and time of measurement on the decrease of relative water content in wild strawberry leaves. Salinity had a much greater effect than the term. In BBCH 15, plants were characterized by a smaller water deficit in leaves. On the other hand, Tytanit ${ }^{\circledR}$ differentiated the RWC and WSD indices in the studied phases, but in an insignificant way - Table 4.

Significant decrease of relative water content in wild strawberry leaves in the second period of measurement at salinity S2 and S3 indicate a high accumulation of salts in the substrate. Soil salinity inhibits plant growth processes, reduces physiological activity and leads to physiological drought deteriorating the water balance of cells (Wróbel et al., 2016).

Moaveni et al. (2011) observed a positive effect of titanium on the relative water content in plant tissue in studies with wheat grown under optimal conditions. The lack of significant influence of this element on the water balance of wild strawberries in this experiment may prove that the action of Tytanit ${ }^{\circledR}$ may depend on the type of stress factor. 
This preparation may also have a different effect on individual plant species.

\section{Fluorimetric analysis}

In the experiment with the wild strawberry, the maximum potential photochemical yield of PSII $\left(\mathrm{Fv} / \mathrm{F}_{\mathrm{M}}\right)$ depended mostly on the date of measurement $\mathrm{P}=37.28 \%$, then on the interaction between salinity and date $\mathrm{P}=32.04 \%$ and on the salinity itself $\mathrm{P}=25.09 \%$ (Tab. 2).

The mean value of $\mathrm{Fv} / \mathrm{F}_{\mathrm{M}}$ was significantly lower in the second term of measurement regardless of the use of Tytanit@ (Tab. 5). The highest salinity of the substrate caused a significant decrease in the value of this parameter in the second term of measurement, and the value of the maximum quantum yield of PSII was almost thirty times lower than the value measured in the first term.

The salinity $\mathrm{P}=26.54 \%$, followed by the measurement date $\mathrm{P}=25.88 \%$ and the interaction between these factors $\mathrm{P}=17.11 \%$ had the most significant effect on the maximum water fission efficiency on the donor side of PSII (Fv/Fo). The error value $(\mathrm{P}=28.21 \%)$, similarly as in the case of carbon dioxide assimilation, exceeded the share of the examined factors; Tytanit ${ }^{\circledR}$ application, term and salinity. This indicates a greater influence of factors not studied in the experiment on the value of $\mathrm{Fv} / \mathrm{Fo}$ in wild strawberry. The mean value of this parameter was significantly lower in the second term of measurement regardless of the use of Tytanit ${ }^{\circledR}$ (Tab. 5). The highest salinity of the substrate caused a significant decrease in the parameter in $\mathrm{BBCH} 60$, the mean value of $\mathrm{Fv} / \mathrm{Fo}$ was almost two hundred times lower than the mean value of this parameter measured in $\mathrm{BBCH} 15$.

Chlorophyll fluorescence is used in ecophysiological studies, monitoring of crops and ecosystems threatened by phytotoxic factors and in plant tolerance to various stress factors (Kalaji et al., 2010). Fluorescence is a highly sensitive photosynthetic plant retraction test that detects changes in the overall bioenergy status of a plant (Schweiger et al. 1996; Michałek et al., 2005).

Table 4. Effect of the performed treatments on ralative water content and water saturation deficit in wild strawberry leaves. Means with same letter were not significantly different by Tukey's comparison at $\mathrm{p}<0.05$ level.

\begin{tabular}{|c|c|c|c|c|c|c|}
\hline \multirow[b]{2}{*}{ Salinity } & \multicolumn{2}{|c|}{ BBCH15 } & \multicolumn{4}{|c|}{ ВBCH60 } \\
\hline & 0 & $\mathrm{~T}$ & average & 0 & $\mathrm{~T}$ & average \\
\hline \multicolumn{7}{|c|}{ RWC (\%) } \\
\hline S1 & $79.04^{\mathrm{a}}$ & $73.50^{\mathrm{a}}$ & $76.27^{\mathrm{A}}$ & $72.83^{\mathrm{a}}$ & $68.75^{\mathrm{ab}}$ & $70.79^{A}$ \\
\hline S2 & $76.28^{a}$ & $73,61^{\mathrm{a}}$ & $74.95^{\mathrm{A}}$ & $44.66^{\mathrm{cd}}$ & $54.81^{\mathrm{bc}}$ & $49.74^{\mathrm{B}}$ \\
\hline S3 & $65.98^{\mathrm{ab}}$ & $71.30^{\mathrm{ab}}$ & $68.64^{A}$ & $37.67^{\mathrm{cd}}$ & $31.21^{\mathrm{d}}$ & $34.44^{\mathrm{C}}$ \\
\hline average & $73.77^{A}$ & $72.80^{A}$ & & $51.72^{B}$ & $51.59^{B}$ & \\
\hline \multicolumn{7}{|c|}{ WSD (\%) } \\
\hline S1 & $20.96^{\mathrm{d}}$ & $26.50^{\mathrm{d}}$ & $23.73^{C}$ & $27.17^{\mathrm{d}}$ & $31.25^{\mathrm{cd}}$ & $29.21^{\mathrm{C}}$ \\
\hline S2 & $23.72^{\mathrm{d}}$ & $26.39^{d}$ & $25.06^{\mathrm{C}}$ & $55.34^{\mathrm{ab}}$ & $45.19^{b c}$ & $50.27^{\mathrm{B}}$ \\
\hline S3 & $34.02^{\mathrm{cd}}$ & $28.70^{\mathrm{cd}}$ & $31.36^{\mathrm{C}}$ & $62.33^{\mathrm{ab}}$ & $68.79^{a}$ & $65.56^{A}$ \\
\hline average & $26.23^{B}$ & $27.20^{B}$ & & $48.28^{A}$ & $48.41^{A}$ & \\
\hline
\end{tabular}

$\mathrm{S} 1$ - substrate with slinity $32.5 \mathrm{mM} \mathrm{L}^{-1}$; S2 - $50 \mathrm{mM} \mathrm{L}^{-1}$; S3 - $100 \mathrm{mM} \mathrm{L}^{-1}$; 0 - lack of Tytanit®; T - 0.3\% solution of Tytanit ${ }^{\circledR}$

Table. 5. Effect of the performed treatments on chlorophyll fluorescence parameters in the leaves of the tested wild strawberry. Means with same letter were not significantly different by Tukey's comparison at $\mathrm{p}<0.05$ level.

\begin{tabular}{|c|c|c|c|c|c|c|}
\hline \multirow[t]{2}{*}{ Salinity } & \multicolumn{2}{|c|}{$\mathrm{BBCH} 15$} & \multirow[t]{2}{*}{ average } & \multicolumn{2}{|c|}{ ВBCH60 } & \multirow[t]{2}{*}{ average } \\
\hline & 0 & $\mathrm{~T}$ & & 0 & $\mathrm{~T}$ & \\
\hline \multicolumn{7}{|c|}{$\mathrm{Fv} / \mathrm{Fm}$} \\
\hline S1 & $0.750^{\mathrm{a}}$ & $0.721^{\mathrm{a}}$ & $0.735^{A}$ & $0.691^{\mathrm{a}}$ & $0.667^{\mathrm{a}}$ & $0.679^{A}$ \\
\hline $\mathrm{S} 2$ & $0.740^{\mathrm{a}}$ & $0.723^{\mathrm{a}}$ & $0.731^{\mathrm{A}}$ & $0.643^{\mathrm{a}}$ & $0.723^{\mathrm{a}}$ & $0.683^{A}$ \\
\hline S3 & $0.716^{\mathrm{a}}$ & $0.699^{\mathrm{a}}$ & $0^{0.708^{A}}$ & $0.006^{\mathrm{b}}$ & $0.025^{\mathrm{b}}$ & $0.014^{\mathrm{B}}$ \\
\hline average & $0.735^{A}$ & $0.714^{\mathrm{A}}$ & & $0.4366^{\mathrm{C}}$ & $0.505^{B}$ & \\
\hline \multicolumn{7}{|c|}{$\mathrm{Fv} / \mathrm{Fo}$} \\
\hline S1 & $3.012^{\mathrm{a}}$ & $2.785^{\mathrm{a}}$ & $2.898^{A}$ & $2.500^{\mathrm{a}}$ & $2.157^{\mathrm{a}}$ & $2.328^{A}$ \\
\hline $\mathrm{S} 2$ & $2.944^{\mathrm{a}}$ & $2.645^{\mathrm{a}}$ & $2.794^{\mathrm{A}}$ & $1.985^{\mathrm{a}}$ & $2.669^{a}$ & $2.327^{\mathrm{A}}$ \\
\hline S3 & $2.650^{\mathrm{a}}$ & $2.562^{\mathrm{a}}$ & $2.606^{\mathrm{A}}$ & $0.006^{\mathrm{b}}$ & $0.027^{\mathrm{b}}$ & $0.015^{B}$ \\
\hline average & $2.868^{\mathrm{A}}$ & $2.664^{\mathrm{A}}$ & & $1.453^{B}$ & $1.743^{B}$ & \\
\hline
\end{tabular}

S1 - substrate with slinity $32.5 \mathrm{mM} \mathrm{L}^{-1}$; S2 - $50 \mathrm{mM} \mathrm{L}^{-1} ; \mathrm{S} 3-100 \mathrm{mM} \mathrm{L}^{-1} ; 0$ - lack of Tytanit@; T - 0.3\% solution of Tytanit® 
According to Angelini et al. (2001), the maximum photochemical yield of PSII $\left(\mathrm{Fv} / \mathrm{F}_{\mathrm{M}}\right)$ is a reliable indicator of the photochemical activity of photosynthetic apparatus. For the majority of plants at the stage of full development and under optimal conditions, the value of this parameter is about 0.83 . In the case of our experiment with wild strawberry, the $\mathrm{Fv} / \mathrm{F}_{\mathrm{M}}$ value for the control was slightly lower, about 0.74 . In turn, the decrease in this parameter value indicates that the plant was exposed to stress factors that damaged PSII functions, reducing the efficiency of electron transport. A significant decrease in $\mathrm{Fv} / \mathrm{F}_{\mathrm{M}}$ values was observed in our experiment with wild strawberries as a result of salt stress.

Michałek and Sawicka (2005) in the experiment with different potato cultivars confirmed the dependence of $\mathrm{Fv} / \mathrm{F}_{\mathrm{M}}$ parameter on the phenological phase of the plant and also on the cultivar. The authors obtained a higher $\mathrm{Fv} / \mathrm{F}_{\mathrm{M}}$ value for the majority of the cultivars studied at full emergence than at full flowering. Similar results were obtained in our study with wild strawberry. Rahimi et al. (2011) recorded a significant decrease in $\mathrm{Fv} / \mathrm{F}_{\mathrm{M}}$ value as a result of salt activity in strawberry physiology. The authors stated that the decreased quantum yield may result from the structural influence of salinity on PSII. Salinity affected reactive photo-system centers directly or through aging of the cells. Salt stress is conducive to leaf aging. $\mathrm{NaCl}$ induces a decrease in the concentration of protein and chlorophyll, which was noted already in 1987 by Kura-Hotta et al. A decrease in the value of maximum water fission efficiency on the donor side of PSII indicates the damage to the photosystem (Xiaoqing et al. 2004).

In plants growing in salinity conditions, the value of $\mathrm{Fv} / \mathrm{Fo}$ ratio decreases, which indicates a decrease in the efficiency of water fission reaction and weakening of photosynthetic electron transport (Pereira et al. 2000). The use of Tytanit® did not have a significant effect on both parameters of photochemical activity (Tab. 2). A lower Fv/Fo value recorded in plants treated with Tytanit ${ }^{\circledR}$ in the first term compared to the control may indicate a negative effect of the preparation on the photosynthetic system. Pereira et al. (2000) showed a decrease in net photosynthesis on citrus as a result of the action of aluminum, which damaged the photosynthetic apparatus. According to the authors, a decrease in Fv/Fo coefficient is an indicator of structural damage that occurs in tylakoids and affects the photosynthetic transport of electrons.

Higher mean values of both $\mathrm{Fm} / \mathrm{Fv}$ and $\mathrm{Fv} / \mathrm{Fo}$ parameters in the second term of measurement in plants treated with Tytanit ${ }^{\circledR}$ may be a reflection of weak support of plant defense mechanisms.

\section{CONCLUSIONS}

The results of the experiment showed a varied effect of Tytanit ${ }^{\circledR}$ on the physiological and biochemical features of wild strawberry grown in salinity.

In general, Tytanit ${ }^{\circledR}$ treatment caused a significant decrease in assimilatory pigments content in older plants and did not affect plants in BBCH 15. On the other hand, preparation significantly decreased proline content in young plants but overall did not affect proline level in older plants. Moreover, Tytanit ${ }^{\circledR}$ had no significant effect on water balance improvement both, in the case of medium salinity and control variants. However, at highest salinity, it deteriorated the water management of plants, increasing the water deficit in the leaves.

The measured parameters of chlorophyll-a fluorescence: $\mathrm{Fv} / \mathrm{FM}$ and $\mathrm{Fv} / \mathrm{Fo}$ proved to be adequate in diagnosing the occurrence of salt stress in wild strawberry. A significant decrease in these values has been demonstrated for saline soil.

The applicability of Tytanit ${ }^{\circledR}$ to mitigate physiological stress in wild strawberry caused by salinity did not produce the desired effect.

\section{REFERENCES}

1. Auriga, A. \& Wróbel, J. (2018). Effect of effective micro-organisms on the proline and mda contents in herb plant. Fresenius Environmental Bulletin, 27(11), pp. 7409-7415.

2. Angelini G., Ragni P., Esposito D., Giardi P., Pompili M.L., Moscardelli L. \& Giardi M.T. (2001). A device to study the effect of space radiation on photosynthetic organism. In Physica Medica - Vol. XVII, Supplement 1, 1st International Workshop on pace Radiation Research and 11 th Annual NASA Space Radiation Health Investigators' Workshop Arona (Italy), May 27-31, 2000.

3. Arnon, D. I., Allen, M. B. \& Whatley, F. R. (1956). Photosynthesis by isolated chloroplasts IV. General 
concept and comparison of three photochemical reactions. Biochimica et Biophysica Acta, 20(3), pp. 449-461. doi: 10.1016/0006-3002(56)90339-0.

4. Belkhodja, R., Morales, F., Medrano \& H., Abadia, J.(1999). Effects of salinity on chlorophyll fluorescence and photosynthesis of barley (Hordeum vulgare L.) grown under a triple-line-source sprinkler system in the field. Photosynthetica, 36(3), pp. 375-387. doi:10.1023/A:1007019918225.

5. Bates, L.S., Waldren, R.P. \& Teare, I.K. (1973). Rapid determination of free proline for water stress studies. Plant and Soil 39, pp. 205-208.

6. Borkowski, J., Kowalczyk, W. \& Felczyńska, A. (2017). Effect of spraying with Tytanit and Wapnovit on the yield and healthiness of chinese cabbage. Zeszyty Naukowe Instytutu Ogrodnictwa 2017, 25: pp. $187-195$.

7. Carvajal, M. \& Alcaraz, C. F. (1998). Why titanium is a beneficial element for plants. Journal of Plant Nutrition, 21(4), pp. 655-664. doi:10.1080/01904169809365433.

8. Chutipaijit, S., Cha-um, S. \& Sompornpailin, K. (2011). High contents of proline and anthocyanin increase protective response to salinity in Oryza sativa L. spp. indica. Australian Journal of Crop Science, 5(10):1191-1198

9. Dias, M. I., Barros, L., Morales, P., Cámara, M., Maria José Alves, M. J., Beatriz, M., Oliveira, P. P., Santos-Buelgaf, C. \& Ferreira, I. (2016). Wild Fragaria vesca L. fruits: A rich source of bioactive phytochemicals. Food and Function, 7(11):4523-4532. doi:10.1039/c6fo01042c.

10. Garcia-Sanchez, F., Jifon, L.J., Carvajala, M. \& Syvertsen, P. (2002). Gas exchange, chlorophyll and nutrient contents in relation to $\mathrm{Na}+$ and $\mathrm{Cl}-$ accumulation in 'Sunburst' mandarin grafted on different rootstocks. Plant Science. Vol. 162, pp. 705-712. doi.org/10.1016/S0168-9452(02)00010-9

11. Gomes, M.A.C., Pestana I.A., Santa-Catarina C., Hauser-Davis R.A. \& Satika Suzuki M. (2017). Salinity effects on photosynthetic pigments, proline, biomass and nitric oxide in Salvinia auriculata Aubl.' Acta Limnologica Brasiliensia, vol. 29, pp. 1-13.

12. Hager A. \& Mayer-Berthenrath T.(1966). Die Isolier- ung und quanttative Bestimung der Carotenoide und Chlorophyll von Blatern, Algen und isolierten Chloroplasten mit Hilfe Dunnschicht-chromatographischer Methoden. Planta. Berlin, 69, pp. 198-217

13. Hrubý, M., Cígler, P. \& Kuzel, S. (2002). Contribution to understanding the mechanism of titanium action in plant. Journal of Plant Nutrition, 25(3), pp. 577-598. doi: 10.1081/PLN-120003383.

14. Islam, M.M., Hoque, M.A., Okuma, E., Banu, M.N.A., Shimoishi, Y., Nakamura,Y. \& Murata Y. (2009). Exogenous proline and glycinebeta- ine increase antioxidant enzyme activities and confer tolerance to cadmium stress in cultured tobacco cells. J. Plant Physiol. 166, pp. 1587-1597.

15. Jamil, A., Riaz S., Ashraf M. \& Foolad M. R. (2011). Gene Expression Profiling of Plants under Salt Stress. Critical Reviews in Plant Sciences, 30 (5): 435-58. https://doi.org/10.1080/07352689.2011.605739.

16. Kalaji, M.H. \& Łoboda, T. (2010). Chlorophyll fluorescence in the study of the physiological state of plants. Publishing house SGGW, Warszawa.

17. Karolewski, P. (1996). Role of proline in higher plants under conditions of abiotic stress. Botanic News. 40(3/4), pp: 67-81

18. Kruczek, A., Ochmian, I., Krupa-Małkiewicz, M. \& Lachowicz, S. (2020). Comparison of morphological, antidiabetic and antioxidant properties of goji fruits. Acta Universitatis Cibiniensis Series E: Food Technology. Vol. XXIV no. 1, pp: 1-14

19. Kura-Hotta, M., Satoh, K. \& Katoh, S.(1987). Relationship between photosynthesis and chlorophyll content during leaf senescence of rice seedlings. Plant Cell Physiol. Vol. 28, pp. 1321-1329

20. Kuzel, S., Hruby, M., Cigler, P., Tlustos, P. \& Nguyen Van, P. (2003). Mechanism of physilogical effects of Titanium leaf sprays on plants grown on soil. Biological Trce Element Research. Vol. 91, pp. $179-189$

21. Lichtenthaler, H. K. \& Wellburn, A. R. (1983). Determinations of total carotenoids and chlorophylls a and b of leaf extracts in different solvents. Biochemical Society Transactions. Portland Press, 11(5), pp. 591-592. doi: 10.1042/bst0110591.

22. Michalski, P. (2008). The effect of Tytanit ${ }^{\circledR}$ on the yield structure and the fruit size of strawberry cv. "Senga Sengana" and "Elsanta". Annales UMCS, Agricultura, 63(3). doi:10.2478/v10081-008-0038-x.

23. Michałek, W. \& Sawicka, B. (2005). Chlorophyll content and photosynthetic activity of medium late potato varieties in arable field conditions in Central and Eastern Poland. Acta Agrophys. 6(1), pp. 183195. 
24. Mir, S., Sirousmehr, A. \& Shirmohammadi, E. (2015). Effect of nano and biological fertilizers on carbohydrate and chlorophyll content of forage sorghum (Speedfeed hybrid). International Journal of Biosciences, 6(4), pp. 157-164. doi: 10.12692/ijb/6.4.157-164.

25. Moaveni, P., Aliabadi Farahani, H. \& Maroufi, K. (2011). Effect of nanoparticles Tio2 spraying on deferent parameters of wheat (Triticum aestivum L.). Advances in Environmental Biology. 2011;5(8), pp. 2217-2219.

26. Muñoz, C., Sanchez-Sevilla, J.F., Botella, M.A., Hoffmann, T., Schwab, W. \& Valpuesta, V. (2011). Polyphenol composition in the ripe fruits of fragaria species and transcriptional analyses of key genes in the pathway. Journal of Agricultural and Food Chemistry, 59(23), pp. 12598-12604. doi: $10.1021 / \mathrm{jf} 203965 \mathrm{j}$.

27. Muscolo, A., Panuccio, M. R. \& Sidari, M. (2003). Effects of salinity on growth, carbohydrate metabolism and nutritive properties of kikuyu grass (Pennisetum clandestinum Hochst). Plant Science, 164(6), pp. 1103-1110. doi: 10.1016/S0168-9452(03)00119-5.

28. Nadi, E., Aynehband A.\& Mojaddam M. (2013). Effect of nano-iron chelate fertilizer on grain yield, protein percent and chlorophyll content of Faba bean (Vicia faba L.). International Journal of Biosciences 3(9), pp: 267-272. doi.org/10.12692/ijb/3.9.267-27

29. Noreen, Z. \& Ashraf, M. (2009). Assessment of variation in antioxidative defense system in salt-treated pea (Pisum sativum) cultivars and its putative use as salinity tolerance markers. Journal of Plant Physiology, 166(16), pp. 1764-1774. doi:10.1016/j.jplph.2009.05.005.

30. Oancea, S. \& Oprean, L. (2011). Anthocyanins, from biosynthesis in plants to human health benefits. Acta Universitatis Cibiniensis Series E: Food Technology. Vol. XV, no.1, pp: 3 - 16

31. Pereira W.E., de Siqueria D.L., Martinez C. A. \& Puiatti M. (2000). Gas exange and chlorophyll fluorescence in four citrus rootstocks under aluminium stress. J. Plant Plant Physiol. 157, pp. 513-520.

32. Parihar, P., Singh S., Singh R., Singh, V.P. \& Prasad, S.M. (2015). Effect of salinity stress on plants and its tolerance strategies: A Review. Environmental Science and Pollution Research, 22 (6), pp. 4056-75. https://doi.org/10.1007/s11356-014-3739-1.

33. Rahimi, A., Biglarifard, A. \& Firozabadi, M. (2011). Influence of $\mathrm{NaCl}$ salinity on some physiological aspect of strawberry cv. Camarosa. Russian Agricultural Sciences, 37(5), pp. 378-384. doi: $10.3103 / \mathrm{S} 1068367411050028$.

34. Romero-Aranda, R., Soria, T. \& Cuartero, J. (2001). Tomato plant-water uptake and plant-water relationships under saline growth conditions. Plant Science, 160(2), pp. 265-272. doi:10.1016/S01689452(00)00388-5.

35. Saha, P., Chatterjee, P. \& Biswas, A. K. (2010). NaCl pretreatment alleviates salt stress by enhancement of antioxidant defense system and osmolyte accumulation in mungbean (Vigna radiata L. Wilczek). Indian journal of experimental biology, 48(6), pp. 593-600.

36. Samadi, N. (2014).Effect of $\mathrm{TiO}_{2}$ and $\mathrm{TiO}_{2}$ nanoparticle on germination, root and shoot length and photosynthetic pigments of Mentha piperita. International Journal of Plant \& Soil Science, 3(4), pp. 408-418. doi: 10.9734/ijpss/2014/7641.

37. Samadi, N., Yahyaabadi, S. \& Rezayatmand, Z. (2015). Stress effects of $\mathrm{TiO}_{2}$ and NP-TiO2 on catalase enzyme and some physiological characteristics of Melissa officinalis L.. European Journal of Medicinal Plants, 9(1), pp. 1-11. doi:10.9734/ejmp/2015/18055.

38. Schweiger, J., Lang, M. \& Lichtenthaler, H.K. (1996). Differences in fluorescence excitation spectra of leaves between stressed and non-stressed plants. J Plant Physiol. 148(5), pp: 536-547

39. Shahbaz, M. \& Ashraf, M. (2013). Improving Salinity Tolerance in Cereals. Critical Reviews in Plant Sciences, 32(4), pp. 237-249. doi: 10.1080/07352689.2013.758544.

40. Shrivastava, P. \& Kumar, R. (2015). Soil salinity: A serious environmental issue and plant growth promoting bacteria as one of the tools for its alleviation. Saudi Journal of Biological Sciences, 22(2), pp. 123-131. doi:10.1016/j.sjbs.2014.12.001.

41. Sultana, N., Ikeda, T. \& Itoh, R. (1999). Effect of $\mathrm{NaCl}$ salinity on photosynthesis and dry matter accumulation in developing rice grains. Environmental and Experimental Botany. Elsevier, 42(3), pp. 211-220. doi:10.1016/S0098-8472(99)00035-0.

42. Wróbel, J., Auriga, A. \& Mielczarek, M. (2016). The effect of salinity and nitrogen deficiency on the changes in selected physiological parameters of common bean (Phaseoleus vulgaris L.) grown in hydroponic cultures. Journal of Ecological Engineering, 17(4), pp. 321-327. doi:10.12911/22998993/64557.

43. Yamaguchi, T. \& Blumwald, E. (2005). Developing salt-tolerant crop plants: challenges and 
opportunities. Trends in Plant Science, 10(12), pp. 615-620. doi:10.1016/J.TPLANTS.2005.10.002.

44. Yamasaki S.\& Dillenburg L.R. (1999). Measurements of leaf relative water content in Araucaria angustifolia. Rev. Bras. Fisiol. Vegetal. 11(2), pp: 69-75.

45. Xiaoqing Y. , Suiqi Z. , Zongsuo L \& Ying S. (2004). Effects of water stress on chlorophyll fluorescence parameters of different drought resistance winter wheat cultivars seedlings. Acta Botanica Boreali-Occidentalia Sinica, 24(5), pp. 812-816.

46. Zhu, J. K. (2001). Plant salt tolerance. Trends in Plant Science, 6(2), pp. 66-71. doi:10.1016/S13601385(00)01838-0. 